\title{
Priming: Getting Ready for Battle
}

\author{
Prime-A-Plant Group: Uwe Conrath, ${ }^{1}$ Gerold J. M. Beckers, ${ }^{1}$ Victor Flors, ${ }^{2}$ Pilar García-Agustín, ${ }^{2}$ \\ Gábor Jakab, ${ }^{3}$ Felix Mauch, ${ }^{4}$ Mari-Anne Newman, ${ }^{5}$ Corné M. J. Pieterse, ${ }^{6}$ Benoit Poinssot, ${ }^{7}$ \\ María J. Pozo, ${ }^{8}$ Alain Pugin, ${ }^{7}$ Ulrich Schaffrath, ${ }^{1}$ Jurriaan Ton, ${ }^{6}$ David Wendehenne, ${ }^{7}$ Laurent Zimmerli, ${ }^{9}$ \\ and Brigitte Mauch-Mani ${ }^{9}$
}

1'Department of Plant Physiology, RWTH Aachen University, 52056 Aachen, Germany; ${ }^{2}$ Área de Fisiología Vegetal, Departamento de Ciencias Experimentales, ESTCE, Universitat Jaume I, Campus Riu Sec, 12071 Castellón, Spain; ${ }^{3}$ Institute of Biology, Faculty of Sciences, University of Pécs, H 7601 Pécs Pf.: 266. Pécs, Hungary; ${ }^{4}$ Department of BiologyPlant Biology, University of Fribourg, 3 Rue Albert Gockel, Fribourg, CH-1700, Switzerland; ${ }^{5}$ Section for Plant Pathology, Royal Veterinary and Agricultural University (KVL), Thorvaldsensvej 40, 1871 Frederiksberg, Denmark; ${ }^{6}$ Section of Phytopathology, Institute of Environmental Biology, Faculty of Science, Utrecht University, PO Box 800.84, 3508 TB Utrecht, The Netherlands; ${ }^{7}$ UMR Plante-Microbe-Environnement INRA 1088/CNRS 5184/ Université de Bourgogne, 17 rue Sully, BP 86510, 21065 Dijon Cédex, France; ${ }^{8}$ Departamento de Microbiología del Suelo y Sistemas Simbióticos, Estación Experimental del Zaidín, CSIC, Profesor Albareda 1, 18008 Granada, Spain; and ${ }^{9}$ Institute of Botany, University of Neuchâtel, Rue Emile Argand 11, PO Box 158, CH-2009 Neuchâtel, Switzerland

Submitted 21 May 2006. Accepted 12 June 2006.

\begin{abstract}
Infection of plants by necrotizing pathogens or colonization of plant roots with certain beneficial microbes causes the induction of a unique physiological state called "priming." The primed state can also be induced by treatment of plants with various natural and synthetic compounds. Primed plants display either faster, stronger, or both activation of the various cellular defense responses that are induced following attack by either pathogens or insects or in response to abiotic stress. Although the phenomenon has been known for decades, most progress in our understanding of priming has been made over the past few years. Here, we summarize the current knowledge of priming in various induced-resistance phenomena in plants.
\end{abstract}

Additional keywords: $\beta$-aminobutyric acid, bacterial lipopolysaccharides, ethylene, jasmonic acid, mycorrhizal fungi, salicylic acid.

Over the past decades, there has been increasing evidence demonstrating that plants can be primed for more efficient activation of cellular defense responses. The priming-caused potentiation of plant defense responses frequently has been associated with enhanced resistance to various biotic or abiotic stresses. For example, cucumber plants that had been attacked by the fungus Colletotrichum lagenarium combated secondary penetration attempts by rapidly depositing effective papillae at the points of attempted pathogen ingress (Kuć 1982). The hypersensitive response (HR) has also been shown to be induced with greater efficacy in plants that had experienced pathogen attack before, resulting in the formation of smaller necrotic HR lesions (Kuć 1995; Ross 1961). The physiological condition in which plants are able to better or more rapidly mount defense responses, or both, to biotic or abiotic stress is called the "primed state" of the plant.

Corresponding author: B. Mauch-Mani; E-mail: brigitte.mauch@unine.ch
Priming is not exclusive to plants but has also been described in animals. A classic example comes from the enhanced response of mammalian monocytes and macrophages to bacterial lipopolysaccharides (LPS). Upon recognizing bacterial LPS, monocytes and macrophages produce various cytokines with important roles in the defense against viruses, bacteria, parasites, or tumor cells (Chen et al. 1992; Raetz et al. 1991). Since the late 1980s, it has been known that the endogenous protein interferon- $\gamma$ plays a role in signaling between mammalian cells attacked by pathogens, induces a primed state that enhances the capacity of monocytes and macrophages to respond to lower doses of LPS in inducing cytokine biosynthesis (Gifford und Lohman-Matthes 1987; Hayes et al. 1991; 1995a; Koerner et al. 1987). Although a few studies have suggested that priming and the subsequent potentiation of cellular defense responses in monocytes and macrophages might be mediated partly at the level of transcription (Hayes et al. 1995b), the molecular mechanisms that regulate priming in monocytes and macrophages remain largely unclear.

Initial investigations on priming and the resulting augmentation of cellular defense responses in plants were performed using parsley cell cultures and a pathogen-associated molecular pattern (PAMP; elicitor) from the cell wall of Phytophthora sojae. Treatment of parsley cell suspensions with either low doses of the Phytophthora sojae elicitor or salicylic acid (SA) did not significantly induce the expression of the defenserelated phenylalanine ammonia-lyase $(P A L)$ gene (Kauss et al. 1992; Thulke and Conrath 1998). However, when parsley cells had been pretreated with SA and then challenged with a low dose of the Phytophthora sojae elicitor, $P A L$ mRNA accumulated to extremely high levels (Fig. 1A), indicating that SA had primed the parsley cells for potentiated expression of elicitorinducible genes, such as PAL. The synthetic SA analogs, 2,6dichloroisonicotinic acid (INA) and benzo $(1,2,3)$ thiadiazole7-carbothioic acid (BTH) were shown to also prime parsley cells for augmented $P A L$ gene expression and enhanced activity of other cellular defense responses. The latter included alterations in ion transport across the plasma membrane (Katz et 


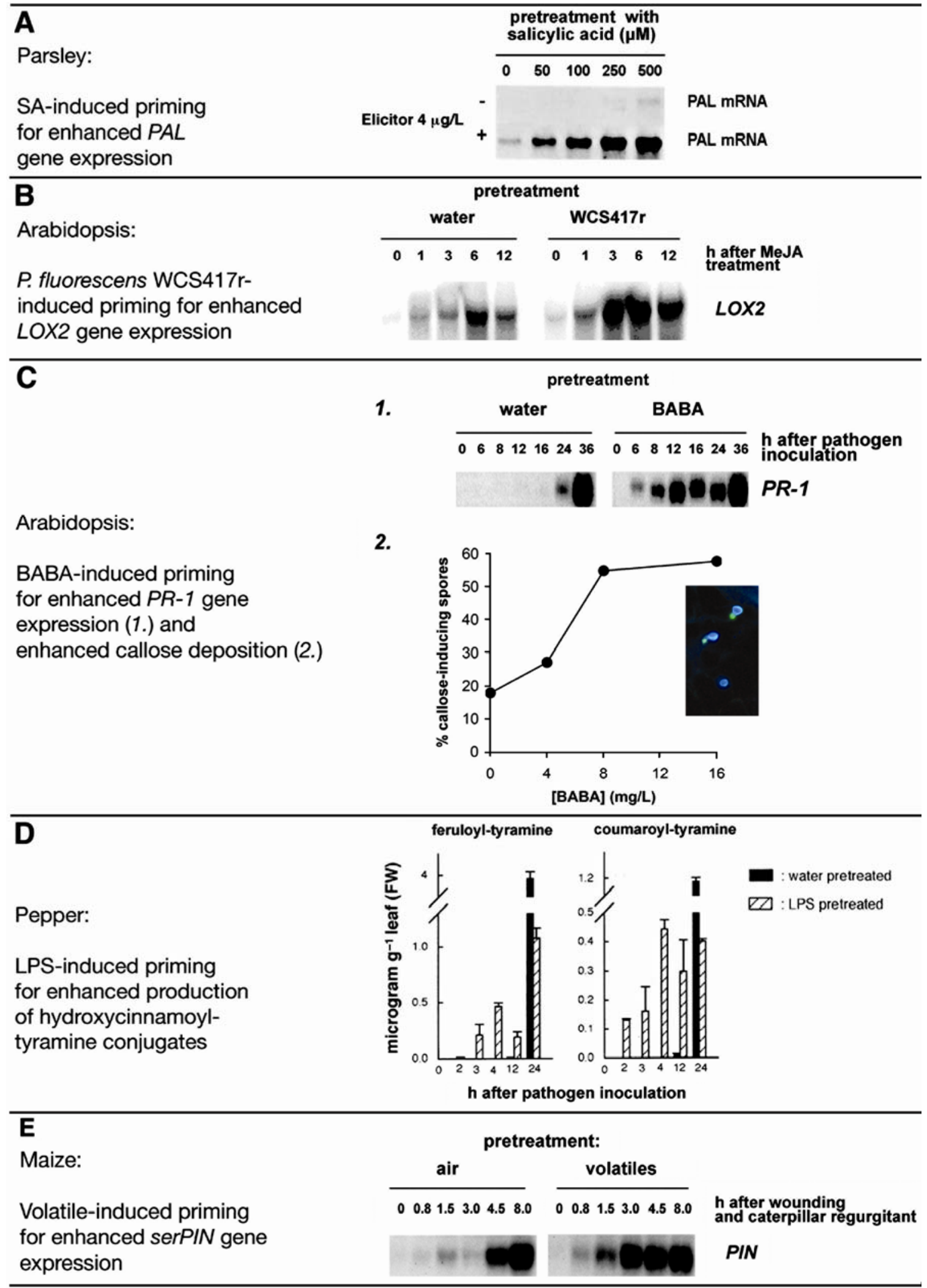

Fig. 1. Priming for enhancement of defense responses in various plant species. A, Salicylic acid (SA)-induced priming for augmented phenylalanine ammonia-lyase ( $P A L)$ gene expression in parsley cell suspensions. Pretreatment with SA results in enhanced $P A L$ activation induced by subsequent treatment with an oomycete cell-wall elicitor (Thulke and Conrath 1998). B, Pseudomomonas fluorescens WCS417r-induced priming in Arabidopsis for enhanced induction of the LOX2 gene upon treatment with methyl jasmonate (MeJA). C, $\beta$-aminobutyric acid (BABA)-induced priming in Arabidopsis for earlier and stronger PR-1 gene expression upon infection by Pseudomonas syringae pv. tomato DC3000 (1.) and BABA-induced priming for enhanced formation of papillae at two days after infection with spores of Hyaloperonospora parastica WACO9 (2.). Inset shows a representative example of germinating $H$. parasitica spores triggering callose depositions in epidermal cells. (J. Ton, unpublished results). D, Lipopolysaccharide (LPS)-induced priming for faster production of the phenolic conjugates coumaroyl tyramine $(\mathrm{CT})$ and feruloyl tyramine (FT) in pepper upon infection with Xanthomonas campestris pv. campestris (Newman et al. 2002). E, Volatile-induced priming for potentiated expression of the jasmonic acid-inducible PIN gene in maize upon treatment by wounding and caterpillar regurgitant (J. Ton and T. C. J. Turlings, unpublished results). 
al. 2002), the activation of various defense genes (Thulke and Conrath 1998), and the synthesis and secretion of phytoalexins (Katz et al. 1998). Besides pathogens, SA, and its analogs, several other biological and chemical agents emerged as potent inducers of priming, which often has been associated with enhanced resistance to a broad spectrum of biotic or abiotic stresses or both.

\section{Priming in systemic acquired resistance.}

Systemic acquired resistance (SAR) is a plant defense state that is induced upon local infection with necrotizing pathogens and which confers resistance to a broad spectrum of attackers (Ryals et al. 1996; Sticher et al. 1997). Induction of SAR requires accumulation of the endogenous signaling molecule SA, which mediates activation of a large set of pathogenesis-related (PR) genes (Durrant and Dong 2004). In Arabidopsis, biological induction of SAR by previous infection with avirulent Pseudomonas syringae pv. tomato DC3000 is not only associated with direct activation of $P R$ genes, it also primes systemic tissues for potentiated activation of defense-related $P A L, P R-1, P R-2$, and $P R-5$ genes. The potentiated induction of defense responses only becomes apparent after further pathogen challenge (Cameron et al. 1999; Kohler et al. 2002; Van Wees et al. 1999) and, therefore, has often been overseen when studying SAR. In Arabidopsis, priming for potentiated $P A L$ expression could be mimicked by pretreatment with low doses of the synthetic SAR inducer $\mathrm{BTH}$, which resulted in augmented accumulation of PAL mRNA after infection with virulent Pseudomonas syringae pv. tomato DC3000 (Kohler et al. 2002). Similarly, SA-primed transgenic tobacco plants carrying chimeric Asparagus officinalis $P R$ $1: \because$ uidA and $P A L-3::$ uidA reporter genes displayed potentiated $P R-1$ and $P A L$ activation after pathogen attack (Mur et al. 1996). These studies indicated a dual role of SA in SAR signaling; either SA directly activates $P R$ gene expression or, alternatively, low doses of SA that do not activate defense genes directly prime the tissue for potentiated defense-gene expression upon subsequent pathogen infection.

In Arabidopsis, several mutants have been identified with an altered priming phenotype. For instance, mutant edrl-1, which had been isolated in a screen for enhanced resistance to Pseudomonas syringae pv. tomato DC3000, also displays increased resistance to a variety of other pathogens, with no constitutive expression of defense-related $P R-1$ and $\beta-1,3$ GLUCANASE (BGL2) genes (Frye and Innes 1998; Van Hulten et al. 2006). However, upon pathogen infection, expression of both genes was augmented in comparison with the expression in infected wild-type plants. In addition, edrl plants showed stronger induction of other defense responses, such as the HR and callose deposition, indicating that edrl plants are constitutively primed for enhanced activation of various defense mechanisms. EDRl encodes a putative mitogen-activated protein kinase (MAPK) kinase kinase (Frye et al. 2001), and the observation that the $e d r l$ mutant is constitutively primed suggests that EDR1 functions as a negative regulator of priming.

Another Arabidopsis gene implicated in priming is NPRl (also known as NIMI or SAII). In response to treatment with avirulent pathogens nprl mutant plants accumulate wild-type levels of SA, but they are unable to express $P R$ genes or SAR (Cao et al. 1994; Delaney et al. 1995; Shah et al. 1997). Not only is the direct activation of defense genes blocked in $n p r l$, but also, priming for potentiation of Pseudomonas syringae pv. tomato DC3000-induced PAL gene expression by low doses of BTH is absent in nprl (Conrath et al. 2002; Kohler et al. 2002). Thus, NPR1 apparently plays a role in SA-mediated priming for enhanced defense-gene expression.

In the cprl and cpr5 mutants of Arabidopsis, which both constitutively express $P R$ genes and SAR (Bowling et al. 1994;
1997), there was constitutive priming for augmented $P A L$ activation upon Pseudomonas syringae pv. tomato DC3000 infection (Conrath et al. 2002; Kohler et al. 2002). The permanently primed state in cprl and cpr5 is likely to be caused by the enhanced levels of SA in these plants (Boch et al. 1998; Clarke et al. 2001). In this context, it is noteworthy that the constitutively enhanced pathogen resistance in $c p r 5-2$ has been ascribed to the potentiated induction of the $P R-1$ gene (Boch et al. 1998).

\section{Priming in beneficial plant-microbe interactions.}

Mutually beneficial interactions between plants and microbes are frequent in nature and either improve plant nutrition, help the plant to overcome biotic or abiotic stresses, or both. In many cases, plant-microbe associations enhance the defense capacity of the plant and effectively ward off a broad spectrum of pathogens (Pozo et al. 2005). For example, colonization of tomato roots by the mycorrhizal fungus Glomus mossae systemically protects the plant against infection by Phytophthora parasitica (Cordier et al. 1998; Pozo et al. 2002). Similarly, selected strains of nonpathogenic plant growth-promoting rhizobacteria (PGPR) can reduce disease in above-ground plant parts through the induction of a defense state that is commonly referred to as rhizobacteria-induced systemic resistance (ISR; Van Loon et al. 1998). In general, systemic resistance responses induced by beneficial microorganisms are not associated with major changes in the expression of defense genes (Pieterse et al. 2002), probably because this would lead to heavy investments in resources and reduced fitness of the host (Heil 2002; Van Hulten et al. 2006).

A common feature of the resistance responses induced by beneficial microorganisms is priming. For example, colonization of tomato roots by mycorrhizal fungi systemically protects the plant against Phytophthora parasitica infection without direct accumulation of PR proteins. However, upon pathogen attack, mycorrhized plants accumulate significantly more PR1a and basic BGL proteins than nonmycorrhized plants. Ultrastructure studies revealed that the former displayed pectin- and callose-containing host cell wall depositions at the sites of subsequent pathogen infection, whereas nonmycorrhizal plants did not (Cordier et al. 1998; Pozo et al. 1999, 2002). Similarly, certain plant growth-promoting fungi (PGPF) were reported to induce priming in plants; challenge infection with the leaf pathogen Pseudomonas syringae pv. lachrymans of cucumber plants that had been preinoculated with the PGPF Trichoderma asperellum T203 leads to potentiated $P R$ gene expression (Shoresh et al. 2005).

Priming in beneficial plant-microbe associations has most extensively been studied in the interaction of plants with ISRinducing PGPR. The first evidence that potentiation of plant defense responses is involved in PGPR-mediated ISR came from experiments with ISR-expressing carnation (Dianthus caryophyllus) in which inoculation with Fusarium oxysporum f. sp. dianthi caused a faster rise in phytoalexin levels than in uninoculated control plants (Van Peer et al. 1991). In bean, $B a$ cillus pumilus SE34 induced ISR against the root-rot fungus $F$. oxysporum f. sp. pisi (Benhamou et al. 1996). Upon challenge infection with the fungus, the root cell walls were rapidly strengthened at the sites of attempted fungal penetration through appositions that contained callose as well as phenolic material and fungal ingress was effectively prevented (Benhamou et al. 1996). In Arabidopsis, ISR triggered by Pseudomonas fluorescens WCS417r is effective against different types of pathogens, but it is not associated with the activation of $P R$ genes (Pieterse et al. 1996). Mutant analysis showed that WCS417r-mediated ISR requires an intact response to jasmonic acid (JA) and ethylene (ET) (Pieterse et al. 1998). Analysis of the Arabidopsis transcriptome revealed that, locally in the roots, ISR-inducing 
WCS417r bacteria elicited a substantial change in the expression of almost 100 genes (Léon-Kloosterziel et al. 2005; Verhagen et al. 2004). However, in systemic leaves, no consistent alteration in gene expression was observed. Thus, the onset of ISR in leaves is not associated with obvious changes in gene expression (Verhagen et al. 2004). In addition, no alterations in the production of either JA or ET could be detected in plants with ISR, suggesting that the induced resistance state is based on an enhanced sensitivity to these plant hormones rather than on an increase in their production (Pieterse et al. 2000). Analysis of the transcriptome of Arabidopsis leaves during ISR to Pseudomonas syringae pv. tomato DC3000 revealed 81 genes with augmented expression, indicating that the plants were primed to respond either faster, more strongly, or both to pathogen attack (Verhagen et al. 2004). An example for such an augmented expression is shown in Figure 1B. The majority of genes with potentiated expression were predicted to be regulated by either JA, ET, or both, thus confirming earlier findings that colonization of the roots by WCS417r-primed Arabidopsis plants for augmented expression of JA- or ET-responsive, or both, genes AtVSP2, PDF 1.2, and HEL (Hase et al. 2003; Van Wees et al. 1999).

Other ISR-inducing PGPR have also been demonstrated to enhance the plant's defense capacity by priming for potentiated expression of defense genes (Ahn et al. 2002; De Meyer et al. 1999; Kim et al. 2004; Tjamos et al. 2005), strongly suggesting that priming is a common feature of PGPR-mediated ISR. Ryu and associates (2004) demonstrated that some PGPR can induce priming by the release of volatiles. For instance, Bacillus subtilis GB03 induces a signaling pathway that is independent of SA, JA, and the NPRI gene, yet it requires ET (Ryu et al. 2004). The GB03 strain produces the C4 carbon compounds 3-hydroxy-2-butanone and (2R,3R)-(-)-2,3 butanediol, which can prime plants for augmented defense responses to attack by herbivores or pathogens (Paré et al. 2005).

\section{Priming by chemicals}

\section{for potentiated responses to biotic stress.}

Priming in BABA-induced resistance to biotic stress. The nonprotein amino acid $\beta$-aminobutyric acid (BABA) is known as a potent inducer of resistance in plants against microbial pathogens (Cohen 2002; Jakab et al. 2001), nematodes (Oka et al. 1999), insects (Hodge et al. 2005), and abiotic stresses (Jakab et al. 2005). Research on the mechanisms of BABA-induced resistance (BABA-IR) in Arabidopsis has shown that this form of induced resistance, like SAR, is mostly based on priming for different pathogen-inducible defense mechanisms. However, the signaling pathway controlling BABA-IR in Arabidopsis is partially different from that of SAR. The pathway that controls BABA-IR against the bacterial pathogen Pseudomonas syringae pv. tomato DC3000 and the fungal pathogen Botrytis cinerea resembles SAR in that it requires endogenous accumulation of SA and an intact NPR1 protein (Zimmerli et al. 2000; 2001). However, in contrast to SAR, a clear priming effect was observed concerning the induction of PRI transcripts in BABAtreated plants (Fig. 1C). Yet, BABA-IR against the oomycete pathogen Hyaloperonospora parasitica was expressed in Arabidopsis genotypes impaired in either the SA, ET, or JA signaling pathway (Zimmerli et al. 2000). Hence, BABA protected Arabidopsis independently of these defense signaling cascades, suggesting an additional mechanism of protection. Interestingly, the expression of BABA-IR against $H$. parasitica coincided with a rapid and enhanced deposition of massive callose-containing papillae (Fig. 1C; Zimmerli et al. 2000). The priming for improved papillae formation provided a plausible explanation for the observed protection against $H$. parasitica, since the resulting increase in resistance could make downstream defense mechanisms, such as PR proteins or camalexin accumulation, no longer critical for resistance.

The correlation between BABA-induced protection and augmented papillae formation, was further investigated in the interaction between Arabidopsis and two necrotrophic fungi, Alternaria brassicicola and Plectosphaerella cucumerina. BABAIR against $A$. brassicicola was not affected in the camelexindeficient mutant pad3-1 or the JA-insensitive mutant coil-1. Furthermore, Arabidopsis mutants impaired in SA, ET, or JA signaling or in camelexin biosynthesis were all capable of expressing BABA-IR against Plectosphaerella cucumerina (Ton and Mauch-Mani 2004). Hence, camalexin accumulation, as well as SA-, JA-, and ET-dependent defense mechanisms could be excluded as potential pathways of BABA-IR against the two fungi. As observed upon infection by $H$. parasitica, cytological observations at the sites of infection by $A$. brassicicola and Plectosphaerella cucumerina revealed that papillae formation was increased in the epidermal cell layer in BABAtreated plants (Ton and Mauch-Mani 2004). Since callose forms an important structural matrix of papillae, 2-deoxy-Dglucose, an inhibitor of callose formation (Jaffe and Leopold 1984), was used to determine the contribution of callose-rich papillae to the protection. The inhibitor decreased the effectiveness of BABA-IR against $A$. brassicicola, suggesting a critical role for callose in BABA-induced protection against this necrotrophic pathogen (Ton and Mauch-Mani 2004). In addition, the callose-deficient mutant pmr4-1 was completely blocked in expressing BABA-IR against Plectosphaerella cucumerina, demonstrating an equally important role for callose in the protection against this pathogen. Interestingly, the priming for enhanced papillae formation at the onset of fungal infection was absent in the abscisic acid (ABA)-signaling mutants abi4-1 and abal-5 (Ton and Mauch-Mani 2004). In addition, exogenous application of ABA mimicked the effect of $\mathrm{BABA}$ on increased formation of callose-rich papillae and resistance against fungal infection. Importantly, both abi4-1 and abal-5 mutants retained their capacity to accumulate callose upon infection, but the BABA-mediated priming of papillae formation was lost. These findings indicate that ABA signaling is involved in the regulation of BABA-induced priming for enhanced papillae formation. Additional support for this conclusion came from the characterization of mutants impaired in BABA-induced sterility (ibs; Ton et al. 2005). Arabidopsis becomes female-sterile when treated with high doses of BABA (Jakab et al. 2001). This fact was used to screen for T-DNA insertion mutants with an altered responsiveness to BABA (Ton et al. 2005). The ibs3 mutant carries a mutation at the $3^{\prime}$ end of the $A B A l$ gene that encodes the ABA biosynthetic enzyme zeaxanthin epoxidase. Ibs3 was impaired in BABA-induced priming for enhanced papillae formation upon infection of BABA-treated plants with $H$. parasitica (Ton et al. 2005).

The molecular mechanisms governing ABA-dependent priming of callose deposition are not clear. However, a possible role for ABA in callose deposition might be deduced from research on abiotic stress, in which different plant SNARE proteins have been implicated in the mediation of ABA-dependent responses (Leymann et al. 1999; Zhu et al. 2002). SNARE proteins have also been linked to disease-resistance mechanisms in the plant cell wall. Mutations in two SNARE-encoding genes, PEN1 and ROR2 (Collins et al. 2003; Lipka et al. 2005), lead to a partial loss of resistance at the level of the plant cell wall, which manifests as an enhanced penetration by nonhost fungal pathogens. PEN1 and ROR2 are both thought to be involved in cellular targeting of vesicles transporting phytoalexins and callose synthase proteins to sites of fungal penetration. This is supported by the high degree of homology between the above-mentioned SNARE genes and tobacco 
NtSyp 121, an ABA-inducible SNARE gene (Collins et al. 2003; Leymann et al. 1999). The results point to a prominent role for ABA in the accelerated formation of callose-rich papillae through enhanced, ABA-dependent transcription or activity of SNARE genes upon pathogen attack.

Priming by other chemicals for potentiated responses to biotic stress. Many chemicals with the capacity to induce stress resistance have been described in plants (Sticher et al. 1997). While most reports described chemicals as elicitors that directly induce defense responses in the absence of pathogens, we focus here on chemicals with the potential to function as inducers of priming.

Biosynthesis of the phytoalexin scoparone has been associated with postharvest resistance to pathogens in Citrus fruits (Ortuño et al. 1997). Brotomax, a commercial product containing aluminum lignosulphonate, induces resistance against $P h y$ tophthora parasitica in Citrus fruits by priming for enhanced production of scoparone upon infection by Phytophthora parasitica parasitica (Ortuño et al. 1997). Similar results have been found for the accumulation of flavanone in Citrus fruits after pathogen infection of Brotomax-pretreated plants (Fuster et al. 1995), indicating that aluminum lignosulphonate can prime Citrus fruit for augmented phytoalexin production.

The strobilurin fungicide Pyraclostrobin enhances resistance of the tobacco cultivar Xanthi nc against infection by Tobacco mosaic virus (TMV) and the wild-fire pathogen Pseudomonas syringae pv. tabaci. Pyraclostrobin also increases TMV resistance in NahG-transgenic tobacco plants (Herms et al. 2002), suggesting that this fungicide enhances TMV resistance in tobacco either by acting downstream of SA in the SA signaling cascade or by functioning independently of SA. Pyraclostrobin did not cause the accumulation of SA-inducible PR-1 defense proteins in infiltrated leaves. However, accumulation of PR-1 was induced more rapidly in Pyraclostrobin-pretreated plants than in water-pretreated controls following TMV infection of tobacco leaves (Herms et al. 2002). These results suggest that Pyraclostrobin, in addition to exerting direct antifungal activity, may also protect plants by priming them for potentiation of subsequent pathogen-induced cellular defense responses. This conclusion is consistent with an earlier report demonstrating that another commercial fungicide, Oryzemate, enhanced the resistance to a bacterial and an oomycete pathogen in Arabidopsis (Yoshioka et al. 2001) and to TMV, Pseudomonas syringae pv. tabaci, and Oidium sp. in tobacco (Nakashita et al. 2002). In this context, it is interesting to note that the activity of the fungicides Metalaxyl, $\mathrm{Cu}(\mathrm{OH})_{2}$, and Fosethyl was impaired in Arabidopsis disease-resistance signal transduction mutants (Molina et al. 1998), while their effectiveness was enhanced in Arabidopsis plants overexpressing NPRl (Friedrich et al. 2001).

Priming by LPS. Innate immune defenses or the nonspecific defense mechanisms that a host uses immediately or within several hours after exposure to nonself molecules can be triggered in eukaryotes by the perception of PAMP, which include LPS and lipooligosaccharides (LOS). LPS are ubiquitous, indispensable components of the cell surface of gram-negative bacteria that have a number of effects in plants, including the ability to prevent the HR induced by avirulent bacteria, priming for more effective induction of plant defense responses such as the oxidative burst, the synthesis of nitric oxide (NO), and the phosphorylation of MAPK (Erbs and Newman 2003). In addition to direct effects on plant tissue, treatment with LPS affect the pattern of accumulation of gene expression and accumulation of certain phenolics in plants in response to subsequent inoculation with virulent or avirulent bacteria. LPS pretreatment of pepper leaves altered patterns of gene expression induced by subsequent challenge with bacteria. Genes encod- ing the PR proteins P6, acidic BGL, and basic BGL were not induced by Salmonella minnesota LPS, while Xanthomonas campestris pv. campestris LPS gave weak, transient expression (Newman et al. 2000). However, pretreatment of pepper leaves with LPS affects the pattern of expression and accumulation of the above-mentioned genes following subsequent challenge with $X$. campestris pv. campestris (avirulent) and $X$. campestris pv. vesicatoria (virulent) (Newman et al. 2000).

Newman and associates (2002) also examined the effects of LPS pretreatment on the accumulation of SA and the synthesis of the phenolic conjugates coumaroyl tyramine (CT) and feruloyl tyramine (FT). The HR response in pepper is associated with increased levels of SA (Newman et al. 2001). CT and FT are suggested to have two possible roles in plant defense, as direct antimicrobial agents and in cell-wall reinforcement (Keller et al. 1996; Newman et al. 2001). LPS had apparently little effect on the timing of accumulation of SA, while the timing of accumulation of FT and CT was considerably altered. LPS pretreatment caused these two compounds to accumulate much more rapidly upon inoculation with $X$. campestris $\mathrm{pv}$. campestris. Yet LPS alone did not induce CT and FT synthesis (Fig. 1D).

Little is known about the mechanisms of perception of LPS and LOS by plants and about the associated signal transduction pathways that trigger LPS-induced plant disease resistance.

Pretreatment of leaves of Arabidopsis with purified $X$. campestris pv. campestris LOS prevented the HR caused by subsequently inoculated avirulent strains of Pseudomonas syringae pv. tomato DC3000 carrying different avirulence genes. The one or more mechanisms by which LOS prevents the HR are as yet unknown, but this phenomenon is associated with an enhanced resistance of the plant tissue to bacteria, which is presumed to occur through LOS-dependent induction or priming for enhanced plant defense responses (Newman et al. 2002).

There is increasing evidence that the activation of the plant innate immunity response upon recognition of PAMP partly resembles the mechanisms of activation of the innate immunity response in mammalian and insect systems. However, it is not clear whether mechanistic parallels for LPS perception by plants, animals, and insects exist, as has been shown for flagellin perception (Zipfel et al. 2004). An understanding of the effects that LPS have on plants and how these are triggered has implications both for the control of bacterial diseases through general nonspecific mechanisms and for biocontrol of bacterial and fungal diseases by beneficial bacteria, which in some cases is believed to occur as a consequence of LPS recognition (Leeman et al. 1995). The challenge ahead is to identify the plant components involved in LPS recognition and subsequent signal transduction. The appreciation that structurally distinct components within LPS may trigger the same plant responses (Silipo et al. 2005) (possibly via different receptors) has substantial implications on the design of genetic or biochemical screens to identify such receptors.

\section{Priming by alterations in primary metabolism.}

Tubers of transgenic potato plants with decreased activity of the plastid ATP/ADP transporter StAATP1 display reduced levels of starch, modified tuber morphology, and altered concentrations of primary metabolites (Tjaden et al. 1998). The spontaneous production of hydrogen peroxide, the endogenous content of SA, and the levels of transcripts of various defenserelated genes are similar in tuber disks of wild-type and StAATP1 antisense potato plants (Linke et al. 2002). However, upon challenging the tissue with various fungal elicitors or culture supernatants of the bacterial pathogen Erwinia carotovora subsp. atroseptica, the StAATPI-silenced tubers exhibited 
highly potentiated activation of defense. This augmented defense included enhanced expression of defense-related genes and augmented incidence of early bursts of reactive oxygen species (ROS) (Linke et al. 2002). The potentiated activation of cellular defense responses in StAATPl plants was not preceded by an increase in endogenous SA levels but, nevertheless, coincided with a strongly enhanced resistance against $E$. carotovora (Linke et al. 2002) and Alternaria solani (Conrath et al. 2003) in the tubers or against Phytophthora infestans in the leaves (Conrath et al. 2003). Thus, inhibition of steps in primary metabolism can lead to the induction of a primed state that sensitizes the tissue for improved elicitation of various cellular defense responses.

\section{Priming for enhanced resistance against abiotic stress.}

Priming by BABA for enhanced responses to abiotic stress. A large number of genes are believed to be involved in plant responses to abiotic stress. By analyzing the expression pattern of genes induced by drought, cold, or high salinity, the existence of distinct mechanisms involved in the regulation of stress-responsive genes has been suggested (Bray 1997; Fowler and Thomashow 2002; Hasegawa et al. 2000; Ingram and Bartels 1996; Pastori and Foyer 2002; Seki et al. 2002a and b; Thomashow 1999). Some of the responses require ABA signaling, while others are ABA-independent (Bray 1997; Shinozaki and Yamaguchi-Shinozaki 1996, 1997, 2000; Thomashow 1999). Other molecules and hormones, such as calcium, JA, and SA have also been suggested to modulate the abiotic stress response of plants (Janda et al. 1999; Kang and Saltveit 2002; Knight et al. 1998).

BABA was found to increase drought and salt stress tolerance in Arabidopsis (Jakab et al. 2005). The protection correlated with an augmented expression of the SA-inducible $P R-1$ and $P R-5$ genes and the ABA-dependent $R A B-18$ and $R D-29 A$ genes upon application of salt and drought stress (discussed above). Mutants impaired in ABA signaling could not be protected by BABA application, while SA-deficient plants showed a reaction that was similar to the one in wild-type plants. However, pretreatment with BABA did not induce ABA accumulation directly but accelerated ABA production following osmotic stress. The augmented ABA production resulted in augmented ABA-inducible gene expression and accelerated stomatal closure (Jakab et al. 2005). These findings demonstrate that BABAinduced tolerance to osmotic stress is based on priming for enhanced adaptation responses rather than on the direct activation of these responses, as is the case in acclimation treatment in which plants are gradually exposed to an increasing stress situation.

\section{Priming in plant-insect interactions.}

Plants release complex mixtures of chemical volatiles upon attack by herbivorous insects. These volatile organic compounds (VOC) are products of diverse metabolic pathways, including aromatic compounds, terpenoid compounds, and derivatives of the octadecanoid pathway that are often referred to as green leaf volatiles (GLV). VOC play an important role in attracting parasitic and predatory insects that are natural enemies of herbivores (Pare and Tumlinson 1999). In addition to this socalled indirect induced defense, there also is evidence that VOC can serve as airborne signals that induce resistance in neighboring, unharmed plants. Since the first evidence for VOC-induced resistance (Baldwin and Schultz 1983), a plethora of publications has supported this form of plant-plant communication (Baldwin et al. 2006; Dicke et al. 2003). In an attempt to identify key volatiles in VOC-induced resistance, experiments were done using purified synthetic volatiles. Apart from methyl jasmonate itself, particularly the C6 GLV were found to trigger JA-dependent defense reactions (Bate and Rothstein 1998; Farag and Pare 2002; Ruther and Furstenau 2005), although there are also studies reporting defense-eliciting activity by terpenoid compounds (Arimura et al. 2000, 2002). However, in all these studies, the VOC-induced defense activity remained rather moderate when compared with insect attack or elicitors from insect regurgitant. Furthermore, the concentrations of the applied volatiles were often unrealistically high and many of the purified volatiles were unable to induce the complete set of JA-responsive defense genes. Therefore, it remains doubtful whether direct defense induction is responsible for the phenomenon of VOC-induced resistance in lab experiments and field trials.

Recently, Engelberth and associates (2004) provided a more plausible mechanism of VOC-induced resistance. The authors discovered that the activity of three GLV, (Z)-3-hexenal, (Z)-3hexen-1-ol, or (Z)-3-hexenyl acetate, is not so much reflected by their ability to activate defense directly but, rather, by a priming effect that leads to an augmented defense expression upon stress treatment. Maize plants pretreated with these C6 volatiles accumulated higher levels of endogenous JA upon elicitation and produced enhanced amounts of VOC upon treatment with caterpillar regurgitant, whereas other typical VOC from maize failed to trigger priming in maize. In support of this, Figure 1E shows that exposition to the total VOC blend from Spodoptera littoralis-infested corn does not directly induce a JA-inducible serine protease inhibitor ( $\operatorname{serPIN)}$ gene but confers a faster and stronger transcriptional activation of this gene after subsequent defense elicitation by applying caterpillar regurgitant on wounded leave areas (J. Ton and T. C. J. Turlings; unpublished results). Hence, VOC from insect-infested plants prime for JA-inducible defense mechanisms in corn. In contrast to these findings, Paschold and associates (2006) recently demonstrated that the VOC blend from Manduca sextainfested native tobacco (Nicotiana attenuate) fails to prime neighboring tobacco plants. Surprisingly, this blend contained all compounds that had previously been shown to induce priming or resistance in other plant species (Paschold et al. 2006). Yet, another recently published study by Kessler and associates (2006) showed that VOC from clipped sagebrush (Artemisia tridentate) prime neighboring tobacco plants for augmented production of secondary metabolites and proteinase inhibitor activity. Together, the studies show that priming by VOC is a common defense strategy in plants, although the identity of VOC triggering the priming may differ among plant species.

The physiological and molecular mechanisms behind VOCinduced priming are largely unknown. Nevertheless, it seems evident that VOC-induced priming targets defense responses that are inducible by JA (Kessler et al. 2006; Paschold et al. 2006). Interestingly, VOC from Spodoptera littoralis-infected corn prime for enhanced expression of only a subset of JAinducible defense genes (J. Ton and T. C. J. Turlings, unpublished results). This suggests that JA is not the only endogenous signal that controls the VOC-induced priming response. In this context, it will be of interest to determine mechanistic similarities between VOC-induced priming and PGPR-mediated ISR, which is also based on priming for JA-dependent defense responses (van Wees et al. 1999; Verhagen et al. 2004).

\section{Priming in monocots.}

In contrast to the large amount of information on inducible defense responses in dicotyledonous plants, the current knowledge of defense in monocots is limited. Both SAR (Kessmann 1994; Sticher 1997) and ISR (Krishnamurthy and Gnanamanickam 1997; 1998) have been described in monocots. Furthermore, master regulatory proteins such as NPR1 have been shown to function in monocots as well (Chern et al. 
2005; Dong 2004), suggesting that dicots and monocots possess similar defense signaling pathways. In fact, several examples of priming for enhanced defense responses have been described for monocots. As mentioned above, maize plants exposed to GLV from neighboring plants are primed to produce enhanced levels of JA and VOC upon subsequent insect attack (Engelberth 2004). Furthermore, treatment with thiamine (vitamin $B_{1}$ ) primes for stronger accumulation of rice $P R-1 a, P R-10$, and $P R-11$ transcripts after challenge with either Xanthomonas oryzae pv. oryzae or Magnaporthe oryzae (Ahn et al. 2005). In barley, preinoculation of the roots with the PGPF Piriformospora indica resulted in enhanced disease resistance and increased tolerance to salt stress without obvious changes in defense-related gene expression (Waller et al. 2005). Overexpression of the Arabidopsis NPRl gene primes wheat plants for faster and stronger activation of the $P R-1$ gene after treatment with BTH or infection by Fusarium graminearum and the potentiation of $P R-1$ expression was associated with an induced resistance to Fusarium head blight disease (Makandar et al. 2006). Taken together, these reports indicate that the priming phenomenon is conserved in monocots.

\section{Does priming modulate early signal transduction pathways with a role in plant-pathogen interactions?}

Pathogens are often recognized by the perception of pathogen-derived molecules (race-specific elicitors or PAMP, depending on the pathosystem), often through sensors or receptors that are localized in the plasma membrane or the cytosol (Bourque et al. 1999; Nürnberger et al. 2004). The molecular interaction initiates a signal transduction cascade and results in activation of various defense responses. Our current knowledge of pathogen-induced signal transduction in plants mainly originates from either the characterization, identification, or both of regulatory components that link receptors to target genes. Almost immediately after pathogen recognition, ion fluxes $\left(\mathrm{Ca}^{2+}, \mathrm{NO}_{3}^{-}, \mathrm{Cl}^{-}, \mathrm{K}^{+}\right)$and changes in the electrical potential differences across the plasma membrane can be detected in plant cells (Pugin et al. 1997; Scheel 1998; Wendehenne et al. 2002). In recent years, some of the kinases that are induced in plants upon contact with pathogens or pathogen-derived signals have been identified as MAPK and calcium-dependent protein kinases (CDPK; Peck 2003). Furthermore, similar to phosphorylation and dephosphorylation, $S$-nitrosylation (the reaction of NO with protein thiols), is emerging as an important post-translational modification of proteins (Lindermayr et al. 2005).

Using different plant and elicitor (PAMP) model systems (e.g., parsley and pep13; tobacco and elicitins; Arabidopsis and flg22), complex networks of signal transduction have emerged (Garcia-Brugger et al. 2006; Gómez-Gómez and Boller 2002; Lebrun-Garcia et al. 1999; Nürnberger et al. 1994). While some pathogen-derived molecules activate a broad array of early responses in certain plant species, they cannot elicit a detectable reaction in others. For example, although elicitin-specific binding sites exist in both tobacco and Arabidopsis (Bourque et al. 1999), elicitins trigger ion fluxes, ROS production, protein kinase activation, and other responses in tobacco but not in Arabidopsis. However, to our knowledge, nobody has checked if elicitins could induce resistance in Arabidopsis via the mechanism of priming. Preliminary data suggest that one molecule can act as a bona fide (direct) elicitor in one species, and as a priming agent in others (B. Poinssot, unpublished results).

So, how can a primed plant be distinguished from a nonprimed one? By now, the only way to detect the primed state is to perform post-challenge defense response assays or even tedious resistance bioassays. Therefore, it becomes increasingly important to identify reliable molecular markers for the primed state. These could be identified by integrating the data obtained from the different priming models.

\section{Putative mechanisms of priming.}

The molecular mechanisms underlying priming are not understood. Hypothetically, the primed state could be based on the accumulation or post-translational modification of one or more signaling proteins that, after being expressed or modified, still remain inactive. Upon subsequent perception of stress, a second signaling event could "hyperactivate" the signaling protein, triggering a potentiated signal transduction. For example, priming might first induce the phosphorylation of a CDPK, leading to conformational change, and then, stress could cause alterations in free $\mathrm{Ca}^{2+}$ levels, thus triggering kinase activity and leading to faster downstream signaling and enhanced transcription of target defense genes. A crucial role for a kinase in priming has been demonstrated in the $i b s l$ mutant affected in a cyclin-dependent kinase-like gene. This mutant has lost the capacity to acquire BABA-induced priming for SA-dependent defenses (Ton et al. 2005).

Another hypothesis suggests that priming enables accelerated defense-gene expression by inducing the accumulation of crucial transcription factors. After stress recognition, signal transduction in primed cells then could directly induce an appropriate set of defense genes, thereby avoiding a preliminary step of transcription factor expression.

\section{Conclusions.}

Priming for enhanced resistance to biotic and abiotic stress obviously is operating via various pathways involved in different metabolic processes. In addition, priming in plants shows phenotypic similarity to potentiation phenomena seen in the defense response of animals and humans. This suggests that the mode of action of priming and the resulting potentiation of cellular defense responses rather than the direct upregulation of defense signaling cascades might be of great advantage for living organisms. Priming fits well in the ecological context of induced resistance. Various studies have demonstrated that activation of inducible defenses involves major costs that affect plant growth and reproduction (Heil 2002). In the case of JA-inducible defenses, the costs are only affordable when the plant is actually exposed to attack by herbivores (Agrawal 1998; Baldwin 1998). A recently published study on the costs and benefits of priming in Arabidopsis demonstrated that the fitness costs of priming are substantially lower than those of the directly induced defense against pathogens (Van Hulten et al. 2006). In addition, it was shown that the benefits of priming outweigh its costs when disease occurs. Consequently, plants in the primed state are efficiently protected against stress without major trade-off effects on commercially and ecologically important traits such as growth and seed set. Hence, from the economic point of view, priming is the plant's solution to the trade-off dilemma between disease protection and costs involved in defense activation. While the lymphocyte-based immune system constitutes an important adaptive defense strategy in humans and animals, priming, as described in this review, also may well represent an important adaptive defense strategy in plants. Apparently, adaptive immunity and induced resistance use priming as a common mechanism by which complex organisms acquire sustainable protection against environmental stress.

\section{ACKNOWLEDGMENTS}

We would like to apologize to our colleagues whose work could not be reviewed here because of space limits. 


\section{LITERATURE CITED}

Agrawal, A. A. 1998. Induced responses to herbivory and increased plant performance. Science 279:1201-1202.

Ahn, I.-P., Park, K., and Kim, C.-H. 2002. Rhizobacteria-induced resistance perturbs viral disease progress and triggers defense-related gene expression. Mol. Cells 13:302-308

Ahn, I.-P., Kim, S., and Lee, Y.-H. 2005. Vitamin $B_{1}$ functions as an activator of plant disease resistance. Plant Physiol. 138:1505-1515.

Arimura, G., Ozawa, R., Shimoda, T., Nishioka, T., Boland, W., and Takabayashi, J. 2000. Herbivory-induced volatiles elicit defense genes in lima bean. Nature 406:512-515.

Arimura, G., Ozawa, R., Nishioka, T., Boland, W., Koch, T., Kuhnemann, F., and Takabayashi, J. 2002. Herbivore-induced volatiles induce the emission of ethylene in neighboring lima bean plants. Plant J. 29:87-98.

Baldwin, I. T. 1998. Jasmonate-induced responses are costly but benefit plants under attack in native populations. Proc. Natl. Acad. Sci. U.S.A. 95:8113-8118.

Baldwin, I. T., and Schultz, J. C. 1983. Rapid changes in tree chemistry induced by damage: Evidence for communication between plants. Science 221:277-279.

Baldwin, I. T., Halitschke, R., Paschold, A., von Dahl, C. C., and Preston, C. A. 2006. Volatile signaling in plant-plant interactions: "Talking trees" in the genomics era. Science 311:812-815.

Bate, N. J., and Rothstein, S. J. 1998. C6-volatiles derived from the lipoxygenase pathway induce a subset of defense-related genes. Plant $\mathrm{J}$. 16:561-569.

Benhamou, N., Kloepper, J. W., Quadt-Hallman, A., and Tuzun, S. 1996. Induction of defense-related ultrastructural modifications in pea root tissues inoculated with endophytic bacteria. Plant Physiol. 112:919-929.

Boch, J., Verbsky, M. L., Robertson, T. L., Larkin, J. C., and Kunkel, B. N. 1998. Analysis of resistance gene-mediated defense responses in Arabidopsis thaliana plants carrying a mutation in CPR5. Mol. PlantMicrobe Interact. 11:1196-1206.

Bourque, S., Binet, M. N., Ponchet, M., Pugin, A., Lebrun-Garcia, A. 1999. Characterization of the cryptogein binding sites on plant plasma membranes. J. Biol. Chem. 274:34699-34705.

Bowling, S. A., Guo, A., Cao, H., Gordon, A. S., Klessig, D. F., and Dong, X. 1994. A mutation in Arabidopsis that leads to constitutive expression of systemic acquired resistance. Plant Cell 6:1845-1857.

Bowling, S. A., Clarke, J. D., Liu, Y., Klessig, D. F., and Dong, X. 1997. The cpr 5 mutant of Arabidopsis expresses both NPR1-dependent and NPR1-independent resistance. Plant Cell 9:1573-1584.

Bray, E. A. 1997. Plant responses to water deficit. Trends Plant Sci. 2:48-54.

Cameron, R. K., Paiva, N. L., Lamb, C. J., and Dixon, R. A. 1999. Accumulation of salicylic acid and $P R-1$ gene transcripts in relation to the systemic acquired resistance (SAR) response induced by Pseudomonas syringae pv. tomato in Arabidopsis. Physiol. Mol. Plant Pathol. 55:121-130.

Cao, H., Bowling, S. A., Gordon, A. S., and Dong, X. 1994. Characterization of an Arabidopsis mutant that is nonresponsive to inducers of systemic acquired resistance. Plant Cell 8:1583-1592.

Chen, T. Y., Lei, M. G., Suzuki, T., and Morrison, D. C. 1992. Lipopolysaccharide receptors and signal transduction pathways in mononuclear phagocytes. Curr. Top. Micro. Immunol. 181:169-188.

Chern, M., Fitzgerald, H. A., Canlas, P. E., Navarre, D. A., and Ronald, P. C. 2005. Overexpression of a rice NPR1 homolog leads to constitutive activation of defense response and hypersensitivity to light. Mol. PlantMicrobe Interact. 18:511-520.

Clarke, J. D., Aarts, N., Feys, B. J., Dong, X., and Parker, J. E. 2001. Constitutive disease resistance requires EDS1 in the Arabidopsis mutants cpr1 and cpr6 and is partially EDS1-dependent in cpr5. Plant J. 26:409-420.

Cohen, Y. 2002. $\beta$-Aminobutyric acid-induced resistance against plant pathogens. Plant Dis. 86:448-457.

Collins, N. C., Thordal-Christensen, H., Lipka, V., Bau, S., Kombrink, E., Qiu, J.-L., Hückelhoven, R., Stein, M., Freialdenhoven, A., Sommerville, S. C., and Schulze-Lefert, P. 2003. SNARE-protein-mediated disease resistance at the plant cell wall. Nature 425:973-977.

Conrath, U., Pieterse, C. M. J., and Mauch-Mani, B. 2002. Priming in plant-pathogen interactions. Trends Plant Sci. 7:210-216.

Conrath, U., Linke, C., Jeblick, W., Geigenberger, P., Quick, W. P., Neuhaus H. E. 2003. Enhanced resistance to Phytophthora infestans and Alternaria solani in leaves and tubers, respectively, of potato plants with decreased activity of the plastidic ATP/ADP transporter. Planta 19:75-83.

Cordier, C., Pozo, M. J., Barea, J. M., Gianinazzi, S., and GianinazziPearson, V. 1998. Cell defense responses associated with localized and systemic resistance to Phytophthora induced in tomato by an arbuscular mycorrhizal fungus. Mol. Plant-Microbe Interact. 11:1017-1028.

Delaney, T. P., Friedrich, L., and Ryals, J. 1995. Arabidopsis signal transduction mutant defective in chemically and biologically induced disease resistance. Proc. Natl. Acad. Sci. U.S.A. 92:6602-6606.
De Meyer, G., Audenaert, K., and Höfte, M. 1999. Pseudomonas aeruginosa 7NSK2-induced systemic resistance in tobacco depends on in planta salicylic acid accumulation but is not associated with PRla expression. Eur. J. Plant Pathol. 105:513-517.

Dicke, M., Agrawal, A. A., and Bruin, J. 2003. Plants talk, but are they deaf? Trends Plant Sci. 8:403-405.

Dong, X. N. 2004. NPR1, all things considered. Curr. Opin. Plant Biol. 7:547-552

Durrant, W. E., and Dong, X. 2004. Systemic acquired resistance. Annu Rev Phytopathol. 42:185-209.

Engelberth, J., Alborn, H. T., Schmelz, E. A., and Tumlinson, J. H. 2004. Airborne signals prime plants against insect herbivore attack. Proc. Natl. Acad. Sci. U.S.A. 101:1781-1785.

Erbs, G., and Newman, M.-A. 2003. The role of lipopolysaccharides in induction of plant defense responses. Mol. Plant Pathol. 4:421-425.

Farag, M. A., and Pare, P. W. 2002. C6-Green leaf volatiles trigger local and systemic VOC emissions in tomato. Phytochemistry 61:545-554.

Fowler, S., and Thomashow, M. F. 2002. Arabidopsis transcriptome profiling indicates that multiple regulatory pathways are activated during cold acclimation in addition to the CBF cold response pathway. Plant Cell 14:1675-1690.

Friedrich, L., Lawton, K., Dietrich, R., Willits, M., Cade, R., and Ryals, J. 2001. NIM1 overexpression in Arabidopsis potentiates plant disease resistance and results in enhanced effectiveness of fungicides. Mol. PlantMicrobe Interact. 14:1114-1124.

Frye, C. A., and Innes, R. W. 1998. An Arabidopsis mutant with enhanced resistance to powdery mildew. Plant Cell 10:947-956.

Frye, C. A., Tang, D., and Innes, R. W. 2001. Negative regulation of defense responses in plants by a conserved MAPKK kinase. Proc. Natl. Acad. Sci. U.S.A. 98:373-378.

Fuster, M. D., García-Puig, D., Ortuño, A., Botía, J. M., Sabater, F., Porras, I., García-Lidón, A., Del Río, J. A. 1995. Selection of Citrus highly productive in secondary metabolites of industrial interest. Modulation of synthesis and/or accumulation processes. Pages 81-85 in: Current Trends in Fruit and Vegetable Phytochemistry. C. García-Viguera, M. Castañer, M. I. Gil, F. Ferreres, and F. A. Tomás-Barberán, eds. CSIC, Madrid.

Garcia-Brugger, A., Lamotte, O., Vandelle, C., Bourque, S., Lecourieux, D., Poinsot, B., Wendehenne, D., and Pugin, A. 2006. Early signaling events induced by elicitors of plant defenses. Mol. Plant-Microbe-Interact. 19:711-724.

Gifford, G. E., and Lohmann-Matthes, M.-L. 1987. Gamma interferon priming of mouse and human macrophages for induction of tumor necrosis factor production by bacterial lipopolysaccharide. J. Natl. Cancer Inst. 78:121-124.

Gómez-Gómez, L., and Boller, T. 2002. Flagellin perception: A paradigm for innate immunity. Trends Plant Sci. 7:251-256.

Hase, S., Van Pelt, J. A., Van Loon, L. C., and Pieterse, C. M. J. 2003. Colonization of Arabidopsis roots by Pseudomonas fluorescens primes the plant to produce higher levels of ethylene upon pathogen infection. Physiol. Mol. Plant Pathol. 62:219-226.

Hasegawa, P. M., Bressan, R. A., Zhu, J. K., and Bohnert, H. J. 2000. Plant cellular and molecular responses to high salinity. Annu. Rev. Plant Physiol. Plant Mol. Biol. 51:463-499.

Hayes, M. P., Enterline, J. C., Gerrard, T. L., and Zoon, K. C. 1991. Priming of human monocytes for enhanced lipopolysaccharide responses: Expression of alpha-interferon, interferon regulatory factors, and tumor necrosis factor. J. Leukoc. Biol. 50:176-181.

Hayes, M. P., Wang, J., and Norcross, M. A. 1995a. Regulation of interleukin-12 expression in human monocytes: Selective priming by interferon-gamma of lipopolysaccharide-inducible $p 35$ and $p 40$ genes. Blood 86:646-650.

Hayes, M. P. Freeman S. L., and Donnelly R. P. 1995b. IFN-gamma priming of monocytes enhances LPS-induced TNF production by augmenting both transcription and mRNA stability. Cytokine 7:427-435.

Heil, M. 2002. Ecological costs of induced resistance. Curr. Opin. Plant Biol. 5:345-350.

Herms, S., Seehaus, K., Koehle, H., and Conrath, U. 2002. A strobilurin fungicide enhances the resistance of tobacco against TMV and Pseudomonas syringae pv. tabaci. Plant Physiol. 130:120-127.

Hodge, S., Thompson, G. A., and Powell, G. 2005. Application of DLbeta-aminobutyric acid (BABA) as a root drench to legumes inhibits the growth and reproduction of the pea aphid Acyrthosiphon pisum (Hemiptera: Aphididae). Bull. Entomol. Res. 95:449-455.

Ingram, J., and Bartels, D. 1996. The molecular basis of dehydration tolerance in plants. Annu. Rev. Plant Physiol. Plant Mol. Biol. 47:377-403.

Jaffe, M. J., and Leopold, A. C. 1984. Callose deposition during gravitropism of Zea mays and Pisum sativum and its inhibition by 2-deoxy-Dglucose. Planta 161:20-26.

Jakab, G., Cottier, V., Toquin, V., Rigoli, G., Zimmerli, L., Métraux, J. P., 
and Mauch-Mani, B. 2001. Beta-aminobutyric acid-induced resistance in plants. Eur. J. Plant Pathol. 107:29-37.

Jakab, G., Ton, J., Flors, V., Zimmerli, L., Métraux, J. P., and MauchMani, B. 2005. Enhancing Arabidopsis salt and drought stress tolerance by chemical priming for its abscisic acid responses. Plant Phsyiol. 139:267-274.

Janda, T., Szalai, G., Tari, I., and Paldi, E. 1999. Hydroponic treatment with salicylic acid decreases the effects of chilling injury in maize (Zea mays L.) plants. Planta 208:175-180.

Kang, H. M., and Saltveit, M. E. 2002. Chilling tolerance of maize, cucumber and rice seedling leaves and roots are differentially affected by salicylic acid. Physiol. Plant 115:571-576.

Katz, V., Thulke, O., and Conrath, U. 1998. A benzothiadiazole primes parsley cells for augmented elicitation of defense responses. Plant Physiol. 117:1333-1339.

Katz, V., Fuchs, A., and Conrath, U. 2002. Pretreatement with salicylic acid primes parsley cells for enhanced ion transport following elicitation. FEBS (Fed. Eur. Biochem. Soc.) Lett. 520:53-57.

Kauss, H., Theisinger-Hinkel, E., Mindermann, R., and Conrath, U. 1992. Dichloroisonicotinic and salicylic acid, inducers of systemic acquired resistance, enhance fungal elicitor responses in parsley cells. Plant J. 2:655-660.

Keller, H., Hohlfeld, H., Wray, V., Hahlbrock, K., Scheel, D., and Strack, D. 1996. Changes in the accumulation of soluble and cell wall-bound phenolics in elicitor-treated cell suspension cultures and fungusinfected leaves of Solanum tuberosum. Phytochemistry 42:389-396.

Kessler, A., Halitschke, R., Diezel, C., and Baldwin, I. T. 2006. Priming of plant defense responses in nature by airborne signaling between $\mathrm{Ar}$ temisia tridentata and Nicotiana attenuata. Oecologia 148:280-292

Kessmann, H., Staub, T., Hofmann, C., Maetzke, T., Herzog, J., Ward, E., Uknes, S., and Ryals, J. 1994. Induction of systemic acquired disease resistance in plants by chemicals. Annu. Rev. Phytopathol. 32:439-459.

Kim, M. S., Kim, Y. C., and Cho, B. H. 2004. Gene expression analysis in cucumber leaves primed by root colonization with Pseudomonas chlororaphis $\mathrm{O} 6$ upon challenge-inoculation with Corynespora cassiicola. Plant Biol. 6:105-108.

Knight, H., Brandt, S., and Knight, M. R. 1998. A history of stress alters drought calcium signaling pathways in Arabidopsis. Plant J. 16:681-687.

Koerner, T. J., Adams, D. O., and Hamilton, T. A. 1987. Regulation of tumor necrosis factor (TNF) expression: Interferon- $\gamma$ enhances the accumulation of mRNA for TNF induced by lipopolysaccharide in murine peritoneal macrophages. Cell. Immunol. 109:437-443.

Kohler, A., Schwindling, S., and Conrath, U. 2002. Benzothiadiazole-induced priming for potentiated responses to pathogen infection, wounding, and infiltration of water into leaves requires the NPR1/NIM1 gene in Arabidopsis. Plant Physiol. 128:1046-1056.

Krishnamurthy, K., and Gnanamanickam, S. S. 1997. Biological control of sheath blight of rice: Induction of systemic resistance in rice by plantassociated Pseudomonas spp. Curr. Sci. 72:331-334.

Krishnamurthy, K., and Gnanamanickam, S. S. 1998. Biological control of rice blast by Pseudomonas fluorescens strain Pf7-14: Evaluation of a marker gene and formulations. Biol. Control 13:158-165.

Kuć, J. 1982. Induced immunity to plant disease. Bioscience 32:854-860.

Kuć, J. 1995. Systemic acquired resistance. Asp. Appl. Biol. 42:235-242.

Lebrun-Garcia, A., Bourque, S., Binet, M., Ouaked, F., Wendehenne, D., Chiltz, A., Schäffner, A., and Pugin, A. 1999. Involvement of plasma membrane proteins in plant defense responses. Analysis of the cryptogein signal transduction in tobacco. Biochimie 81:663-668.

Leeman, M., Vanpelt, J. A., Denouden, F. M., Heinsbroek, M., Bakker, P. A. H. M., and Schippers, B. 1995. Induction of systemic resistance against Fusarium wilt of radish by lipopolysaccharides of Pseudomonas fluorescens. Phytopathology 85:1021-1027.

Léon-Kloosterziel, K. M., Verhagen, B. W. M., Keurentjes, J. J. B., Van Pelt, J. A., Rep, M., Van Loon, L.C., and Pieterse, C. M. J. 2005. Colonization of the Arabidopsis rhizosphere by fluorescent Pseudomonas spp. activates a root-specific, ethylene-responsive PR-5 gene in the vascular bundle. Plant Mol. Biol. 57:731-748.

Leyman, B., Geelen. D., Quintero, F. J., and Blatt, M. R. 1999. A tobacco syntaxin with a role in hormonal control of guard cell ion channels. Science 283:537-540.

Lindermayr, C., Saalbach, G., and Durner, J. 2005. Proteomic identification of $S$-nitrosylated proteins in Arabidopsis. Plant Physiol. 137:921-930.

Linke, C., Conrath, U., Jeblick, W., Betsche, T., Mahn, A., Duering, K. and Neuhaus, H. E. 2002. Inhibition of the plastidic ATP/ADP transporter protein primes potato tubers for augmented elicitation of defense responses and enhances their resistance against Erwinia carotovora. Plant Physiol. 129:1607-1615.

Lipka, V., Dittgen, J., Bednarek, P., Bhat, R., Wiermer, M., Stein, M. Landtag, J., Brandt, W., Rosahl, S., Scheel, D., Llorente, F., Molina, A., Parker, J., Somerville, S., and Schulze-Lefert, P. 2005. Pre- and postin- vasion defenses both contribute to nonhost resistance in Arabidopsis. Science 310:1180-1183.

Makandar, R., Essig, J. S., Schapaugh, M. A., Trick, H. N., and Shah, J. 2006. Genetically engineered resistance to Fusarium head blight in wheat by expression of Arabidopsis NPR1. Mol. Plant-Microbe Interact. 19:123-129.

Molina, A., Hunt, M. D., and Ryals, J. A. 1998. Impaired fungicide activity in plants blocked in disease resistance signal transduction. Plant Cell 10:1903-1914.

Mur, L. A. J., Brown, I. R., Darby, R. M., Bestwick, C. S., Bi, Y.-M., Mansfield, J. W., and Draper, J. 1996. Salicylic acid potentiates defense gene expression in tissue exhibiting acquired resistance to pathogen attack. Plant J. 9:559-571.

Nakashita, H., Yoshioka, K., Yasuda, M., Nitta, T., Arai, Y., Yoshida, S., and Yamaguchi, I. 2002. Probenazole induces systemic acquired resistance in tobacco through salicylic acid accumulation. Physiol. Mol. Plant Pathol. 61:197-203.

Newman, M.-A., Daniels, M. J., and Dow, J. M. 1997. The activity of Lipid A and core components of bacterial lipopolysaccharides in the prevention of the hypersensitive response in pepper. Mol. PlantMicrobe Interact. 10:926-928.

Newman, M.-A., von Roepenack-Lahaye, E., Daniels, M. J., and Dow, J. M. 2000. Lipopolysaccharides and plant responses to phytopathogenic bacteria. Mol. Plant Pathol. 1:25-31.

Newman, M.-A., von Roepenack-Lahaye, E., Parr, A., Daniels, M. J., and Dow, J. M. 2001. Induction of hydroxycinnamoyl-tyramine conjugates in pepper by Xanthomonas campestris, a plant defense response activated by hrp gene-dependent and hrp gene-independent mechanisms. Mol. Plant-Microbe Interact. 14:785-792.

Newman M.-A., von Roepenack-Lahaye, E., Parr, A., Daniels, M. J., and Dow, J. M. 2002. Prior exposure to lipopolysaccharide potentiates expression of plant defenses in response to bacteria. Plant J. 29:487-495.

Nürnberger, T., Nennstiel, D., Jabs, T., Sacks, W., Hahlbrock, K., and Scheel, D. 1994. High affinity binding of a fungal oligopeptide elicitor to parsley plasma membranes triggers multiple defense responses. Cell 78:449-460.

Nürnberger, T., Brunner, F., Kemmerling, B., and Piater, L. 2004. Innate immunity in plants and animals: Striking similarities and obvious differences. Immunol Rev. 198:249-266.

Oka, Y., Cohen, Y., and Spiegel, Y. 1999. Local and systemic induced resistance to the root-knot nematode in tomato by DL- $\beta$-amino- $n$-butyric acid. Phytopathol. 89:1138-1143.

Ortuño, A., Botia, J. M., Fuster, M. D., Porras, I., García-Lidón, A., and del Río, J. A. 1997. Effect of scoparone (6-7-dimethoxicoumarin) biosynthesis on the resistance of tangelo Nova, Citrus paradisi and Citrus aurantium fruits against Phytophthora parasitica. J. Agric. Food Chem. 45:2740-2743.

Paré, P. W., and Tumlinson, J. H. 1999. Plant volatiles as a defense against insect herbivores. Plant Physiol. 121:325-332.

Paré, P. W., Farag, M. A., Krishnamachari, V., Zhang, H., Ryu, C. H., and Kloepper J. W. 2005. Elicitors and priming agents initiate plant defense responses. Photosynth. Res. 85:149-159.

Paschold, A., R. Halitschke, and I. T. Baldwin. 2006. Using 'mute' plants to translate volatile signals. Plant J. 45:275-91.

Pastori, G. M., and Foyer, C. H. 2002. Common components, networks, and pathways of cross-tolerance to stress. The central role of "redox" and abscisic acid-mediated controls. Plant Physiol. 129:460-468.

Peck, S. 2003. Early phosphorylation events in biotic stress. Curr. Opin. Plant Biol. 6:334-338.

Pieterse, C. M. J., Van Wees, S. C. M., Hoffland, E., Van Pelt, J. A., and Van Loon, L.C. 1996. Systemic resistance in Arabidopsis induced by biocontrol bacteria is independent of salicylic acid accumulation and pathogenesis-related gene expression. Plant Cell 8:1225-1237.

Pieterse, C. M. J., Van Wees, S. C. M., Van Pelt, J. A., Knoester, M., Laan, R., Gerrits, H., Weisbeek, P. J., and Van Loon, L. C. 1998. A novel signaling pathway controlling induced systemic resistance in Arabidopsis. Plant Cell 10:1571-1580.

Pieterse, C. M. J., Van Pelt, J. A., Ton, J., Parchmann, S., Mueller, M. J., Buchala, A. J., Métraux, J.-P., and Van Loon, L. C. 2000. Rhizobacteria-mediated induced systemic resistance (ISR) in Arabidopsis requires sensitivity to jasmonate and ethylene but is not accompanied by an increase in their production. Physiol. Mol. Plant Pathol. 57:123-134.

Pieterse, C. M. J., Van Wees, S. C. M., Ton, J., Van Pelt, J. A., and Van Loon, L. C. 2002. Signaling in rhizobacteria-induced systemic resistance in Arabidopsis thaliana. Plant Biol. 4:535-544.

Pozo, M. J., Azcón-Aguilar, C., Dumas-Gaudot, E., and Barea, J. M. 1999. $\beta$-1,3-glucanase activities in tomato roots inoculated with arbuscular mycorrhizal fungi and/or Phytophthora parasitica and their possible involvement in bioprotection. Plant Sci. 141:149-157. 
Pozo, M. J., Cordier, C., Dumas-Gaudot, E., Gianinazzi, S., Barea, J. M., and Azcón-Aguilar, C. 2002. Localized vs. systemic effect of arbuscular mycorrhizal fungi on defense responses to Phytophthora infection in tomato plants. J. Exp. Bot. 53:525-534.

Pozo, M. J., Van Loon, L. C., and Pieterse, C. M. J. 2005. Jasmonates-Signals in plant-microbe interactions. J. Plant Growth Regul. 23:211-222.

Pugin, A., Frachisse, J.-M., Tavernier, E., Bligny, R., Gout, E., Douce, R., and Guern, J. 1997. Early events induced by the elicitor cryptogein in tobacco cells: Involvement of a plasma membrane NADPH oxidase and activation of glycolysis and the pentose phosphate pathway. Plant Cell 9:2077-2091.

Raetz, C. R., Ulevitch, R. J., Wright, S. D., Sibley, C. H., Ding, A., and Nathan, C. F. 1991. Gram-negative endotoxin: An extraordinary lipid with profound effects on eukaryotic signal transduction. FASEB (Fed. Am. Soc. Exp. Biol.) J. 5:2652-2660.

Ruther, J., and Furstenau, B. 2005. Emission of herbivore-induced volatiles in absence of a herbivore response of Zea mays to green leaf volatiles and terpenoids. Z. Naturforsch. 60:743-756.

Ryals, J. A., Neuenschwander, U. H., Willits, M. G., Molina, A., Steiner, H.Y., and Hunt, M. 1996. Systemic acquired resistance. Plant Cell 8:18091819.

Ryu, C.-M., Farag, M. A., Hu, C.-H., Reddy, M. S., Kloepper J. W., and Paré, P. W. 2004. Bacterial volatiles induce systemic resistance in Arabidopsis. Plant Physiol. 134:1017-1026.

Ross, A. F. 1961. Systemic acquired resistance induced by localized virus infections in plants. Virology 14:340-358.

Scheel, D. 1998. Resistance response physiology and signal transduction. Curr. Opin. Plant Biol. 1:305-310.

Shah, J., Tsui, F., and Klessig, D. F. 1997. Characterization of a salicylic acid-insensitive mutant (sail) of Arabidopsis thaliana, identified in a selective screen utilizing the SA-inducible expression of the TMS2 gene. Mol. Plant-Microbe Interact. 10:69-78.

Seki, M., Ishida, J., Narusaka, M., Fujita, M., Nanjo, T., Umezawa, T., Kamiya, A., Nakajima, M., Enju, A., Sakurai, T., Satou, M., Akiyama, K., Yamaguchi-Shinozaki, K., Carninci, P., Kawai, J., Hayashizaki, Y., and Shinozaki, K. 2002a Monitoring the expression pattern of around 7,000 Arabidopsis genes under ABA treatments using a full-length cDNA microarray. Funct. Integr. Genomics 2:282-291.

Seki, M., Narusaka, M., Ishida, J., Nanjo, T., Fujita, M., Oono, Y., Kamiya, A., Nakajima, M., Enju, A., Sakurai, T., Satou, M., Akiyama, K., Taji, T., Yamaguchi-Shinozaki, K., Carninci, P., Kawai, J., Hayashizaki, Y., and Shinozaki, K. 2002b. Monitoring the expression profiles of 7000 Arabidopsis genes under drought, cold and high-salinity stresses using a full-length cDNA microarray. Plant J. 31:279-292.

Shinozaki, K., and Yamaguchi-Shinozaki, K. 1996. Molecular responses to drought and cold stress. Curr. Opin. Biotechnol. 7:161-167.

Shinozaki, K., and Yamaguchi-Shinozaki, K. 1997. Gene expression and signal transduction in water-stress response. Plant Physiol. 115:327-334.

Shinozaki, K., and Yamaguchi-Shinozaki, K. 2000. Molecular responses to dehydration and low temperature: Differences and cross-talk between two stress signaling pathways. Curr. Opin. Plant Biol. 3:217-223.

Shoresh, M., Yedidia, I., and Chet, I. 2005. Involvement of jasmonic acid/ethylene signaling pathway in the systemic resistance induced in cucumber by Trichoderma asperellum T203. Phytopathol. 95:76-84.

Silipo, A., Molinaro, A., Sturiale, L., Dow, J. Maxwell, Erbs, G., Lanzetta, R., Newman, M.-A., and Parrilli, M. 2005. The elicitation of plant innate immunity by lipooligosaccharide of Xanthomonas campestris. J. Biol. Chem. 280:33660-33668.

Sticher, L., Mauch-Mani, B., and Métraux, J. P. 1997. Systemic acquired resistance. Annu. Rev. Phytopathol. 35:235-270.

Thomashow, M. F. 1999. Plant cold acclimation: Freezing tolerance genes and regulatory mechanisms. Annu. Rev. Plant Physiol. Plant Mol. Biol. 50:571-599.
Thulke, O., and Conrath, U. 1998. Salicylic acid has a dual role in the activation of defense-related genes in parsley. Plant J. 14:35-42.

Tjaden, J., Möhlmann, T., Kampfenkel, K., Henrichs, G., and Neuhaus H. E. 1998. Altered plastidic ATP/ADP-transporter activity influences potato (Solanum tuberosum L.) tuber morphology, yield and composition of tuber starch. Plant J. 16:531-540.

Tjamos, S. E., Flemetakis, E., Paplomatas, E. J., and Katinakis, P. 2005. Induction of resistance to Verticillium dahliae in Arabidopsis thaliana by the biocontrol agent K-165 and pathogenesis-related proteins gene expression. Mol. Plant-Microbe Interact. 18:555-561.

Ton, J., and Mauch-Mani, B. 2004. $\beta$-amino-butyric acid-induced resistance against necrotrophic pathogens is based on ABA-dependent priming for callose. Plant J. 38:119-130.

Ton, J., Jakab, G., Toquin, V., Lavicoli, A., Flors, V., Maeder, M. N., Métraux, J.-P., and Mauch-Mani, B. 2005. Dissecting the $\beta$-aminobutyric acid-induced priming pathways in Arabidopsis. Plant Cell 17:987999.

Van Hulten, M., M. Pelser, L. C. Van Loon, C. M. J. Pieterse, and J. Ton 2006. Costs and benefits of priming for defense in Arabidopsis. Proc. Natl. Acad. Sci. U.S.A. 103:5602-5607.

Van Loon, L. C., Bakker, P. A. H. M., and Pieterse, C. M. J. 1998. Systemic resistance induced by rhizosphere bacteria. Annu. Rev. Phytopathol. 36:453-483.

Van Peer, R., Niemann, G. J., and Schippers, B. 1991. Induced resistance and phytoalexin accumulation in biological control of fusarium wilt of carnation by Pseudomonas sp. strain WCS417r. Phytopathol. 81:728-734.

Van Wees, S. C. M., Luijendijk, M., Smoorenburg, I., Van Loon, L. C., and Pieterse, C. M. J. 1999. Rhizobacteria-mediated induced systemic resistance (ISR) in Arabidopsis is not associated with a direct effect on expression of known defense-related genes but stimulates the expression of the jasmonate-inducible gene Atvsp upon challenge. Plant Mol. Biol. 41:537-549.

Verhagen, B. W. M., Glazebrook, J., Zhu, T., Chang, H.-S., van Loon, L. C., and Pieterse, C. M. J. 2004. The transcriptome of rhizobacteria-induced systemic resistance in Arabidopsis. Mol. Plant-Microbe Interact. 17:895-908.

Waller, F., Achatz, B., Baltruschat, H., Fodor, J., Becker, K., Fischer, M., Heier, T., Hückelhoven, R., Neumann, C., von Wettstein, D., Franken, P., and Kogel, K.-H. 2005. The endophytic fungus Piriformospora indica reprograms barley to salt-stress tolerance, disease resistance, and higher yield. Proc. Natl. Acad. Sci. U.S.A. 102:13386-13391.

Wendehenne, D., Lamotte, O., Frachisse, J.-M., Barbier-Brygoo, H., and Pugin, A. 2002. Nitrate efflux is an essential component of the cryptogein signaling pathway leading to defense responses and hypersensitive cell death in tobacco. Plant Cell 14:1937-1951.

Yoshioka, K., Nakashita, H., Klessig, D. F., and Yamaguchi, I. 2001. Probenazole induces systemic acquired resistance in Arabidopsis with a novel type of action. Plant J. 25:149-157.

Zhu, J. K. 2002. Salt and drought stress signal transduction in plants. Annu. Rev. Plant Biol. 53:247-73.

Zhu, J., Zhizhong, G., Zhang, C., Song, C. P., Damsz, B., Inan, G., Koiwa, H., Zhu, J. K., Hasegawa, P. M., and Bressan, R. 2002. A syntaxin protein in Arabidopsis controls abscisic acid-mediated and non-abscisic acid mediated responses to abiotic stress. Plant Cell 14:3009-3028.

Zimmerli, L., Jakab, G., Métraux, J.-P., and Mauch-Mani, B. 2000. Potentiation of pathogen-specific defense mechanisms in Arabidopsis by betaaminobutyric acid. Proc. Natl. Acad. Sci. U.S.A. 97:12920-12925.

Zimmerli, L., Métraux, J.-P., and Mauch-Mani, B. 2001. $\beta$-aminobutyric acid-induced protection of Arabidopsis against the necrotrophic fungus Botrytis cinerea. Plant Physiol. 126:517-523.

Zipfel, C., Robatzek, S., Navarro, L., Oakeley, E. J., Jones, J. D. G., Felix, G., and Boller, T. 2004. Bacterial disease resistance in Arabidopsis through flagellin perception. Nature 428:764-767. 